\title{
Kararlı Anjina Pektorisli Hastalarda Koroner Arter Lezyon Şiddetinin Eritrosit Dağılım Genişliği ve Ayak Bileği-Kol Basınç indeksi ile iliş̧kisi
}

The Relationship between Red Cell Distribution Width and

Ankle-Brachial Pressure Index of the Coronary Artery Lesion Severity in Patients with Stable Angina Pectoris

Kayihan Karaman', Barış Aygüç², Arif Arısoy', Metin Karayakalı', Samet Yılmaz', Serhat Karaman 3 , Cemal Aslan 4 , Ataç Çelik'

' Gaziosmanpaşa Üniversitesi Tıp Fakültesi, Kardiyoloji A.D, Tokat, Türkiye

${ }^{2}$ Kozluk Devlet Hastanesi, Kardiyoloji Kliniği, Batman, Türkiye

${ }^{3}$ Gaziosmanpaşa Üniversitesi Tıp Fakültesi, Acil Tıp A.D, Tokat, Türkiye

${ }^{4}$ Gaziosmanpaşa Üniversitesi Tıp Fakültesi, Kardiyovasküler Cerrahi A.D., Tokat, Türkiye

Yazışma Adresi / Correspondence:

Kayıhan Karaman

Gaziosmanpaşa Üniversitesi Tıp Fakültesi, Kardiyoloji Ana Bilim Dalı, Tokat 60100, Tokat, Türkiye

T: $+905468023542 \quad$ E-mail: kay55han@hotmail.com

Geliş Tarihi / Received : 16.04.2018 Kabul Tarihi / Accepted : 20.05.2018

$\ddot{0} z$

Amaç Ayak bileği-kol basınç indeksi (AKi), noninvaziv ve ucuz bir metod olup yaşlı popülasyonda periferik arter hastalığının (PAH) tanımlanması için kullanılır. PAH'nın bir göstergesi olarak AKi, koroner arter hastalığını (KAH) tahmin etmek için yaygın bir şekilde kullanılmaktadır. Eritrosit dağıım genişliği (EDG) dolaşımdaki eritrositlerin boyutlarındaki değişkenliğin bir ölçüsüdür. EDG'deki artışlar hem kararlı hem de kararsız haldeki KAH ile ilișkilidir. Bu çalıșmada, kararlı anjina pektoris (KAP) hastalarında EDG ve AKi belirteçlerinin SYNTAX skoru (SS) kullanılarak koroner lezyon şiddeti üzerine prediktif bilgi sağlayıp sağlayamayacağını araştırmayı amaçladık. Sakarya Tip Dergisi, 2018, 8(2):311-319)

Gereç ve Çalışmaya 109 KAP hastası dahil edildi. Hastalar önce 40 hasta normal koroner arterler ve 69 hasta KAH grubuna ayrlarak değerlendirildi. Yöntem Sonrasında KAH hasta grubu, KAH şiddetini anjiyografik olarak derecelendiren SS'na göre iki ayrı alt gruba (SS 1-22 ( $n=32$ ) ve SS >22 $(n=37)$ ayrılarak incelendi. $p<0.05$ anlamlı kabul edildi.

Bulgular Çok değişkenli regresyon analizi EDG ve AKi'nin KAH varlığının bağımsız birer prediktörü olduğunu gösterdi (sırasıyla; OR: $6.209, p=0.001$ ve OR: - $2.342, p<0.001$ ). Fakat aynı analiz AKi'nin KAH şiddetini öngörmede EDG'den daha iyi olduğunu gösterdi (sırasıyla; OR: 1.568, $p=0.215$ ve OR: $-1.540, p<0.001$.

Sonuç Koroner arter hastalığı varlığında EDG'nin anlamlı derecede arttığı, AKi'nin anlamlı derecede azaldığı görülmüștür. KAH varlığını öngörmede EDG ve AKi'nin kullanışlı birer değişken olduğu tespit edilmiştir. AKi, KAH'ın şiddetini tahmin etmede EDG'den daha güçlü bir öngördürücüdür

Anahtar Bilek-brakiyal indeksi; eritrosit dağlım genişliği; SYNTAX skoru; anjina pektoris

kelimeler

\section{Abstract}

Objective Ankle-brachial pressure index (ABI) is a noninvasive and inexpensive method used to identify peripheral arterial disease (PAD) in the elderly population. As a marker of $\mathrm{PAD}, \mathrm{ABI}$ is widely used to predict coronary artery disease (CAD). Red cell distribution width (RDW) is a measure of the variability in the size of erythrocytes in circulation. Increases in RDW are associated with both stable and unstable CAD. In this study, we aimed to investigate whether RDW and ABI markers could provide predictive information on coronary lesion complexity using SYNTAX score (SS) in patients with stable angina pectoris (SAP). ( Sakarya Med J, 2018, 8(2):311-319).

Materials and A total of 109 patients with SAP were included in the study. Patients were divided into 40 patients with normal coronary arteries and 69 Methods patients with CAD. Subsequently, the CAD patient group was examined by separating two subgroups (SS 1-22 ( $\mathrm{n}=32)$ and SS $>22(\mathrm{n}=37)$ ) according to the SS that rated CAD severity as angiography. $\rho<0.05$ was considered significant

Results Multivariate regression analysis showed that RDW and ABI were independently predictors of CAD (OR: 6.209, $p=0.001$ and OR: -2.342 , $p<0.001$, respectively). However, the same analysis showed that ABI was better than RDW in predicting the severity of CAD (OR: 1.568, $p=0.215$ and OR: $-1.540, p<0.001)$.

Conclusion In the presence of CAD has been shown that RDW increases significantly and ABI decreases significantly. It has also been found that RDW and $A B I$ are useful variables for predicting the presence of $C A D$. $A B I$ is a strong predictor of the severity of $C A D$ than RDW.

Keywords Ankle-brachial index; red cell distribution width; SYNTAX score; angina pectoris 
Sakarya TIp Dergisi 2018;8(2):311-319 KARAMAN ve Ark.

KAP Hastalarında KAH'nin EDG ve AKi ile ilişskis

\section{Giriş}

Periferik arter hastalı̆ı (PAH) genellikle ateroskleroz nedeniyle alt ekstremite arterlerinin progresif daralması sonucu ortaya çıkar ve kardiyovasküler (KV) morbidite ve mortalitenin önemli bir göstergesidir. ${ }^{1}$ Ayak bileği-kol basınç indeksi (AKi), noninvaziv ve ucuz bir yöntem olup yaşlı popülasyonda PAH'nın tanımlanması için kullanılır. AKi, invaziv anjiyografi ile kıyaslandığında oldukça yüksek duyarlılık ve özgüllüğe sahiptir ( $>\% 90$, her biri için). ${ }^{2}$ PAH'nın bir göstergesi olarak AKi, koroner arter hastalığın (KAH) tahmin etmek için yaygın bir şekilde kullanılmaktadır. ${ }^{3,4}$ SYNTAX (SYNergy between percutaneous coronary intervention with TAXus and cardiac surgery) skoru (SS) tamamen koroner anatomi ve lezyon özelliklerinden kaynaklanan kapsamlı bir anjiyografik skorlama sistemidir. SS ile her birey için en uygun revaskülarizasyon türü (perkütan veya cerrahi) belirlenebilir ve ayrıca revaskülarizasyon sonrası orta dönem izlem için prognostik bilgi sağlanabilir. $^{5}$

Eritrosit dağılım genişliği (EDG) dolaşımdaki eritrositlerin boyutlarındaki değişkenliğin bir ölçüsüdür. EDG'nin genel popülasyondaki KV mortaliteyi bağımsız olarak öngördüğünü gösteren klinik çalışmalar mevcuttur. EDG'deki artışlar hem kararlı hem de kararsız haldeki KAH ile ilişkilidir. ${ }^{6}$ Aynı zamanda, geniş bir Çin kohortunda koroner anjiyografi ile saptanan KAH varlığı ve şiddeti ile EDG düzeyleri arasında anlamlı bir korelasyonun varlığı gösterilmiştir.7 Bu çalışmada, kararlı anjina pektoris (KAP) hastalarında EDG ve AKi belirteçlerinin koroner lezyon şiddeti üzerine öngördürücü bilgi sağlayıp sağlamadığını araştırmayı amaçladık.

\section{Materyal Ve Yöntemler Çalışma Topluluğu}

Kesitsel tipte ve tanımlayıcı olarak planlanan çalışmamızın katılımcıları Ocak 2016-Mart 2017 tarihleri arasında hastanemize başvuran, Avrupa Kardiyoloji Derneği KAP kılavuzuna göre Test Öncesi Olasilığı \%15-85 arasındaki orta riskli KAP'li hastalarda egzersiz stres testi veya miyokart perfüzyon sintigrafisi sonrasında iskemi saptanarak koroner anjiyografi yapılan 109 hastadan oluşturuldu. ${ }^{8} 109$ hasta önce 40 hasta normal koroner arterler ve 69 hasta KAH grubuna ayrlarak değerlendirildi. Sonrasında hasta grubu, KAH şiddeti anjiyografik olarak derecelendiren SS'na (http://www.syntaxscore.com) göre iki ayrı alt gruba (SS 1-22 ( $n=32)$ ve SS >22 ( $n=37)$ ) ayrılarak incelendi. ${ }^{9}$ Bilinen KAH (geçirilmiş miyokart enfarktüsü, anjiyoplasti ve koroner baypas hikayesi), kararsız anjina ve akut koroner sendrom ile başvuran hastalar, kalp yetmezliği (ejeksiyon fraksiyo$\mathrm{nu}<\% 50$ ), geçirilmiş inme ve PAH olanlar, atriyal fibrilasyon, kalp kapak hastalı̆ı, akut veya kronik iltihaplı hastalık, şiddetli karaciğer veya böbrek yetmezliği, morbid obezite, malignite olan hastalar çalışma dışı bırakıldı. Buna ek olarak, anemi ve kan transfüzyon öyküsü olan olgular da dışlandı.

\section{Temel Değişkenler}

Hasta yaşı, cinsiyet, geçmiş hastalık öyküsü, sigara içme alışkanlıkları ve güncel ilaçlar dikkatli bir şekilde tespit edildi. Kan örnekleri, bir gece açlıktan sonra rutin kimya için başvuru esnasında alındı. Hemoglobin, beyaz kan hücresi sayısı ve EDG değerleri Pentra DX 120 analiz cihazı (ABX, Montpellier, Fransa) ile ölçüldü. Anemi, hemoglobin konsantrasyonu erkeklerde $<13$ mg/dl, kadınlarda $<12 \mathrm{mg} /$ dl olarak tanımlandı. Vücut kütle indeksi (VKi) ağılık/boy2 $(\mathrm{kg} / \mathrm{m} 2)$ olarak hesaplandı. Serum kreatin, açlık kan şekeri, trigliseritler, toplam kolesterol, düşük ve yüksek dansiteli lipoprotein kolesterol düzeyleri, hemoglobin, toplam lökosit sayısı, eritrosit sedimentasyon hızı (ESH) ve C-reaktif protein (CRP) laboratuar kayıtlarından elde edildi. 


\section{Koroner Anjiyografi ve SYNTAX Skoru}

Koroner anjiyografi için geleneksel bir anjiyografi cihazı (Artis zee; Siemens, Erlangen, Almanya) kullanıldı. Anjiyogramlar iki farklı uzman tarafından nitel olarak değerlendirildi ve stenoz oranını değerlendirmek için ortalama değerler kullanıldı. Anjiyografik olarak aterosklerotik lezyon bulunmayan grup (normal koroner arterler) KAH olmayan grup olarak tanımlandı. SS'na göre değerlendirildiğinde, KAH olmayan 40 hastanın skoru 0'dı. Koroner arterlerin herhangi birinde aterosklerotik lezyonlara sahip hastalar KAH olan grup olarak tanımlandı. Tıkayıcı KAH, çapı $1.5 \mathrm{~mm}$ 'den büyük bir epikardiyal veya yan dal damarın çapında \%50'nin üzerinde darlığın varlığı olarak tanımlandı ve SS algoritması kullanılarak prospektif olarak hesaplanan SS'nu sağlamak üzere ayrı ayrıskorlandı ve puanlandı.9 KAH olan hastalar SS'na göre iki gruba (1-22 ve >22) ayrıldı.

\section{Ayak Bileği-Kol Basınç İndeksinin Değerlendirilmesi}

Ayak bileği-kol basınç indeksi, sabah 12 saatlik açlıktan sonra ve koroner anjiyografi işleminden önce ölçüldü. Ölçümler en az 10 dakika istirahat sonrası yapıldı. Brakiyal ve arka tibial arterlerin (ölçülemezse dorsalis pedis arterleri kullanıldı) sistolik basınçlarının belirlenmesi, şişirilebilir manşonların bulunduğu civa manometresi yardımıla yapıldı. Bir el Doppleri, Korotkoff seslerinin daha iyi duyulabilmesi için kullanıldı. Maksimum ayak bileği sistolik basıncının maksimum brakiyal sistolik basıncına bölünmesi ile her bir alt ekstremite için AKi değeri hesaplandı. Sağ ve sol AKi arasındaki farklar açısından en düşük AKi değerlendirme için kullanıldı. AKi ölçümü, PAH'nın yönetimi için Transatlantik Topluluklar Arası Konsensüs (TASC II) kılavuzlarına göre yapıld.. ${ }^{10}$

Bu araştırma tek merkezli bir çalışmadır. Çalışma protokolü kurumumuzdaki etik komite tarafından onaylandı ve bilgilendirilmiş onam formu tüm katılımcılar tarafından dolduruldu. Çalışma Helsinki Deklarasyonu ile uyumlu idi.

\section{İstatistiksel Analiz}

Sürekli değişkenler ortalama standart sapma şeklinde verildi. Kategorik değişkenler ise yüzde olarak verildi. Sürekli değişkenler arasındaki fark için normal dağılıma uygunluğu Kolmogorow-Smirnov testi ile sınandıktan sonra; Student's t-testi kullanıldı. Kategorik değişkenler arasındaki fark içinse ki-kare testi kullanıldı. Korelasyon analizinde Pearson korelasyon testi kullanıldı. Koroner arter hastalığı varlığını öngördüren parametreler çok değişkenli regresyon analizi ile değerlendirildi. Tek değişkenli regresyon analizinde $p<0.25$ olan değişkenler için çok değişkenli regresyon analizi yapıldı. Receiver Operating Characteric (ROC) analizi ile KAH varlığını öngördüren EDG ve AKI için kestirim değeri hesaplandı. Yine, KAH olan grup içinde yüksek SS varlığını öngördüren parametreler çok değişkenli regresyon analizi ile değerlendirildi. ROC analizi ile yüksek SS varlığını öngördüren AKi için kestirim değeri hesaplandı. Tüm testler, PASW Statistics (SPSS 18.0 for Windows, Inc, Chicago, IL, USA) kullanılarak gerçekleştirildi ve $p<0.05$ anlamlı kabul edildi.

\section{Bulgular}

Kararlı anjina pektorisli toplam 109 hasta çalışmaya dahil edildi. KAH olan ve olmayan şeklinde 2 grup oluşturulduğunda, gruplara ait temel özellikler Tablo 1'de verilmiştir. KAH olan grupta diğer grupla karşılaşııııldığında yaş, hipertansiyon, diyabetes mellitus ve hiperlipidemi varlığı, sistolik kan basıncı, CRP, EDG ve AKi açısından anlamlı fark saptandı (Şekil 1). Çok değişkenli analizde yaş, hiperlipidemi varlığı, EDG ve AKi'nin anjiyografik KAH varlığının bağımsız öngördürücüleri olduğu bulunmuştur (Tablo 2). Yine bu grup içinde EDG ve AKi arasında anlamlı negatif korelasyon bulun-
Sakarya Tip Dergis

2018;8(2):311-319

KARAMAN ve Ark.

KAP Hastalarında KAH'nın

EDG ve AKi ile ilişkisi 
Sakarya Tip Dergisi 2018;8(2):311-319 KARAMAN ve Ark. KAP Hastalarinda KAH'nin EDG ve AKi ile ilişkis muştur ( $r=-0.381, p<0.001)$ (Şekil 1a). Doğrusal regresyon analizi EDG ve AKi arasında bağımsız bir ilişki olduğunu göstermiştir ( $=-0.067, p<0.001)$. Ayrıca, KAH varlığı yaş, hipertansiyon, sistolik kan basıncı, CRP ve EDG ile pozitif, AKi ile negatif değerde anlamlı korelasyon göstermiştir (Tablo 2). EDG'nin hem ESH ( $r=0.296, p=0.005)$ hem de CRP ( $r=0.312, p=0.007)$ ile anlamlı pozitif korelasyonunun, AKi'nin hem ESH $(r=-0.288, p=0.006)$ hem de CRP $(r=-0.272, p=0.01)$ ile anlamlı negatif korelasyonunun olduğu görülmüştür. Ancak, doğrusal regresyon analizi yapıldığında bu verilerden sadece EDG ve CRP arasında bağımsız ilişki olduğu görülmüştür ( $=0.261, p=0,014)$.

\begin{tabular}{|c|c|c|c|}
\hline & $\mathrm{KAH}-(\mathrm{n}=40)$ & $\mathrm{KAH}+(\mathrm{n}=69)$ & $p$ \\
\hline Yaş & $53.9 \pm 9.9$ & $65.0 \pm 7.6$ & $<0.001$ \\
\hline Erkek cinsiyet, n (\%) & $21(52.5)$ & $44(63.8)$ & 0.248 \\
\hline Diyabetesmellitus, n (\%) & $10(25)$ & $34(49.3)$ & 0.013 \\
\hline Hipertansiyon, n (\%) & $13(32.5)$ & $49(71)$ & $<0.001$ \\
\hline Sigara, n (\%) & $8(20)$ & $11(15.9)$ & 0.590 \\
\hline Hiperlipidemi, n (\%) & $11(27.5)$ & $40(58)$ & 0.002 \\
\hline Kreatinin, mg/dl & $0.81 \pm 0.17$ & $0.85 \pm 0.19$ & 0.201 \\
\hline Düşük yoğunluklu lipoprotein kolesterol, mg/dl & $125.0 \pm 30.3$ & $135.1 \pm 40.8$ & 0.250 \\
\hline Total kolesterol, mg/dl & $186.7 \pm 33.8$ & $196.9 \pm 45.2$ & 0.305 \\
\hline Vücut kitle indeksi, kg/m2 & $28.7 \pm 3.4$ & $29.2 \pm 4.6$ & 0.539 \\
\hline Sistolik kan basıncı, mmHg & $124.6 \pm 11.5$ & $137.8 \pm 13.8$ & $<0.001$ \\
\hline Diyastolik kan basıncı, mmHg & $70.7 \pm 8.8$ & $73.2 \pm 9.6$ & 0.181 \\
\hline Syntax Skor & - & $20.9 \pm 9.1$ & $<0.001$ \\
\hline Glomerülerfiltrasyon hızı, ml/min/1.73 m2 & $96.8 \pm 22.2$ & $90.3 \pm 20.3$ & 0.125 \\
\hline Eritrosit sedimentasyon hızı, mm/h & $18.23 \pm 10.92$ & $25.00 \pm 21.31$ & 0.067 \\
\hline C-reaktif protein, mg/L & $5.42 \pm 5.10$ & $9.41 \pm 9.19$ & 0.017 \\
\hline Total lökosit sayısı, ×109/L & $7.67 \pm 2.03$ & $7.76 \pm 1.80$ & 0.852 \\
\hline Eritrosit dağılım genişliği, (\%) & $12.8 \pm 0.59$ & $13.6 \pm 0.79$ & $<0.001$ \\
\hline Ayak bileği-kol basınç indeksi & $1.08 \pm 0.04$ & $0.84 \pm 0.09$ & $<0.001$ \\
\hline
\end{tabular}
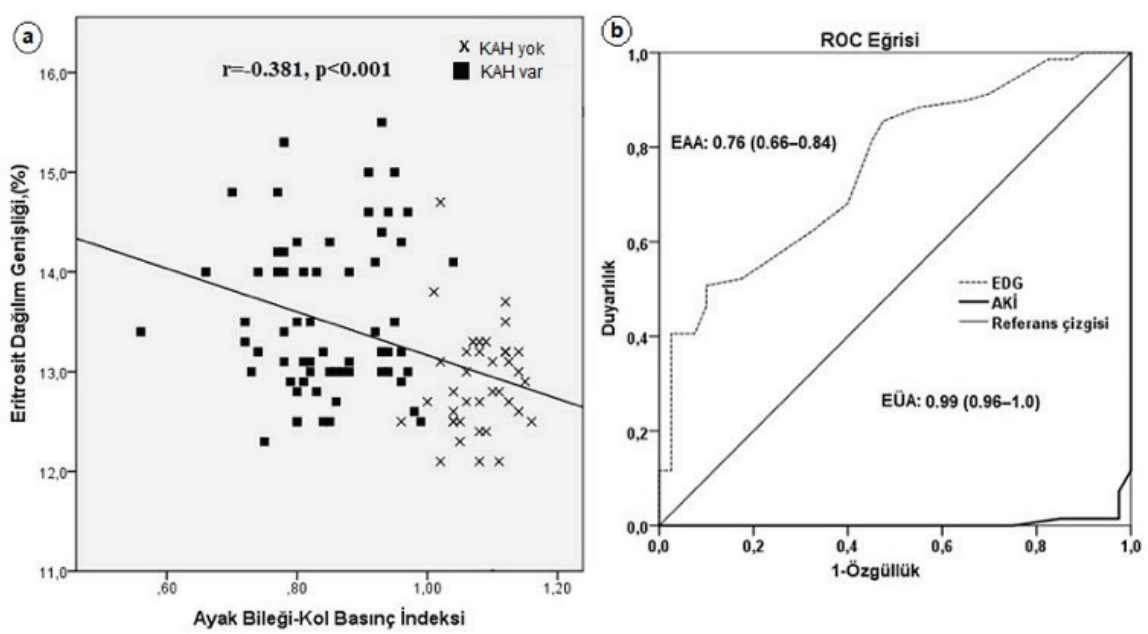

Şekil 1: a) Tüm hastalar değerlendirildiğinde AKi ve EDG arasındaki ilişki. b) ROC analizi ile EDG ve AKi'nin KAH varlığını öngörmede duyarlılık ve özgüllüğü. AKi: Ayak bileği-kol basınç indeksi, EDG: Eritrosit dağılım genişliği, EAA: Eğri altındaki alan, EÜA: Eğri üstündeki alan, KAH: Koroner arter hastalığı, ROC: Receiver operating characteric. 


\begin{tabular}{|c|c|c|c|c|c|c|}
\hline & \multicolumn{2}{|c|}{$\begin{array}{c}\text { Pearson } \\
\text { Korelasyon Analizi }\end{array}$} & \multicolumn{2}{|c|}{$\begin{array}{l}\text { Tek Değişkenli } \\
\text { Regresyon Analizi }\end{array}$} & \multicolumn{2}{|c|}{$\begin{array}{c}\text { Çok Değişkenli } \\
\text { Regresyon Analizi }\end{array}$} \\
\hline & $r$ & $\rho$ & Odds Oranı & $p$ & Odds Oranı & $\rho$ \\
\hline Yaş & 0.504 & $<0.001$ & 1,152 & & 1,116 & 0,006 \\
\hline Diyabetesmellitus & 0.158 & 0.137 & 2,914 & 0,014 & 0,815 & 0,760 \\
\hline Hipertansiyon & 0.305 & 0.003 & 5,466 & & 4,218 & 0,054 \\
\hline Hiperlipidemi & 0.190 & 0.073 & 3,636 & 0,003 & 9,018 & 0,003 \\
\hline Sistolik kan basıncı & 0.235 & 0.026 & 1,086 & & 1,028 & 0,324 \\
\hline C-reaktif protein & 0.248 & 0.018 & 1,056 & 0,025 & 1,015 & 0,799 \\
\hline Eritrosit dağılım genişliği & 0.224 & 0.034 & 5,306 & & 6,209 & 0,001 \\
\hline Ayak bileği-kol basınç indeksi & -0.744 & $<0.001$ & $-1,154$ & & $-2,342$ & \\
\hline
\end{tabular}
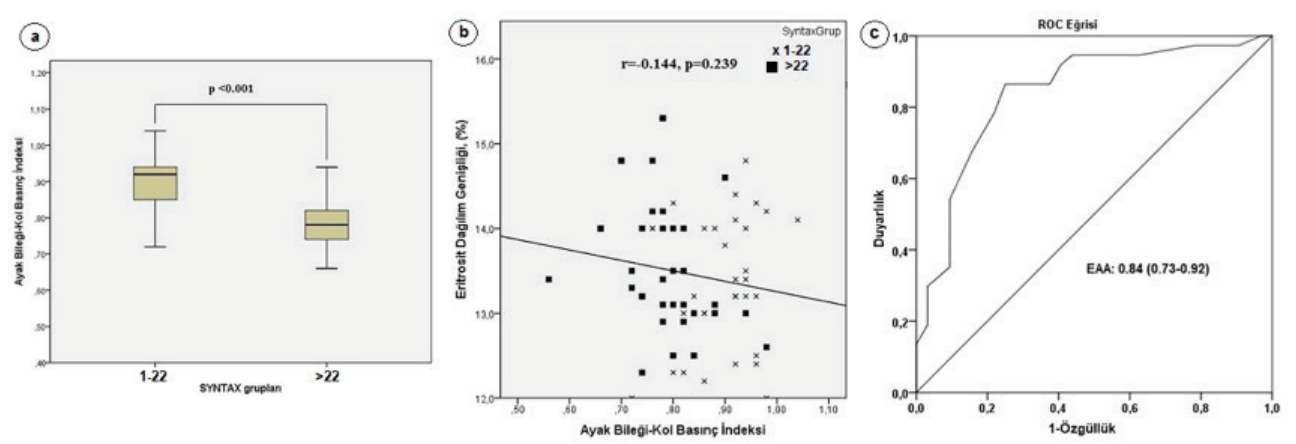

Şekil 2: a) SYNTAX grupları arasında AKi değerlerinin dağıımı. b) KAH hastaları SYNTAX grupları açısından değerlendirildiğinde AKi ve EDG arasındaki ilişki. c) ROC analizi ile AKi'nin yüksek SYNTAX skoru varlığını öngörmede duyarllık ve özgüllüğü. AKi: Ayak bileği-kol basınç indeksi, EDG: Eritrosit dağılım genişliği, EAA: Eğri altındaki alan, KAH: Koroner arter hastalığı, ROC: Receiver operating characteric.

Receiver operating characteric analizinde EDG'nin kestirim değeri >\%13.3 alındığında, KAH varlığıกı \%50.7 duyarllık ve \%90.0 özgüllük ile öngördürdüğü saptandı (Eğrinin altındaki alan: 0.76, \%95 güven aralığı: $0.66-0.84, p<0.001$ ). AKi için yapılan ROC analizinde AKi'nin kestirim değeri $\leq 0.99$ alındığında, KAH varlığını \%98.6 duyarlıık ve \%97.5 özgüllük ile öngördürdüğü saptandı (Ĕgrinin altındaki alan: $0.99, \% 95$ güven aralı̆ı: 0.96-1.0, p<0.001) (Şekil 1b). Çok değişkenli analizde diyabetes mellitus varlığı (Odds oranı $(O R)=2.64, \% 95$ güven aralı̆ı $(G A)=1.08-6.47, p=0.033$ ) ve yaş $(\mathrm{OR}=1.08 \% 95 \mathrm{GA}=1.02-1.14, \mathrm{p}=0.008)$ yükselmiş bir $\mathrm{EDG}$ değerinin $(>\% 13.3)$ bağımsız öngördürücüleri olarak tanımlandı. Aynı analiz AKi için yapıldığında hipertansiyon ( $O R=0.23, \% 95$ $\mathrm{GA}=0.07-0.71, \rho=0.01)$, hiperlipidemi varlığı $(\mathrm{OR}=0.29, \% 95 \mathrm{GA}=0.10-0.85, \mathrm{p}=0.024)$ ve yaş $(\mathrm{OR}=0.88 \% 95 \mathrm{GA}=0.82-0.94, p<0.001)$ azalmış bir AKi değerinin $(\leq 0.99)$ bağımsı öngördürücüleri olarak tanımlandı.

Koroner arter hastalı̆ı olan grup SS'na göre 2 gruba ayrıldığında (1-22, >22), gruplara ait temel özellikler Tablo 3'te verilmiştir. SS'larındaki artış EDG'nde eşzamanlı bir artış ile ilişkili değildi ve EDG ile SS arasında anlamlı korelasyon yoktu $(r=0.02, p=0.826)$. Aynı gruplar AKi açısından değerlendirildiğinde, SS'larındaki artış AKi'nde eşzamanlı anlamlı bir azalma ile ilişkiliydi ve AKi ile SS arasında negatif değerde anlamlı korelasyon vardı ( $r=-0.55, p<0.001)$ (Şekil 2a). Yine bu grup 
Sakarya TIp Dergisi

2018;8(2):311-319

KARAMAN ve Ark

KAP Hastalarninda KAH'nin EDG ve AKi ile ilişkis içinde yapılan korelasyon analizinde AKi ve EDG arasında anlamlı ilişki saptanmamıştır ( $r=-0.144$, $\mathrm{p}=0.239)$ (Şekil 2b). Yüksek (>22) ve düşük SS'ları (1-22) olan hastalar tek değişkenli analizde karşılaştıııldığında, SS yüksek olan grupta erkek cinsiyet, HT varlığı ve vücut kitle indeksi değerleri daha yüksek izlenirken, AKi değeri anlamlı olarak daha düşük izlendi. Çok değişkenli regresyon analizinde ise sadece AKi (OR=-1.540, \%95 GA (-2.322_-1.022), p<0.001) yüksek SS'nun bağımsız öngördürücüsü olarak tanımlanmıştır (Tablo 4).

\begin{tabular}{|c|c|c|c|}
\hline & SS 1-22 $(n=32)$ & SS $>22(n=37)$ & $p$ \\
\hline Yaş, yıl & $64.9 \pm 7.5$ & $65.1 \pm 7.7$ & 0.911 \\
\hline Erkek cinsiyet, n (\%) & $15(46.9)$ & $29(78.4)$ & 0.007 \\
\hline Diyabetesmellitus, n (\%) & $14(43.8)$ & $14(54.1)$ & 0.393 \\
\hline Hipertansiyon, n (\%) & $28(87.5)$ & $22(59.5)$ & 0.009 \\
\hline Sigara, n (\%) & $4(12.5)$ & $6(16.2)$ & 0.700 \\
\hline Hiperlipidemi, n (\%) & $19(59.4)$ & $21(56.8)$ & 0.826 \\
\hline Kreatinin, mg/dL & $0.82 \pm 0.23$ & $0.89 \pm 0.15$ & 0.173 \\
\hline Düşük yoğunluklu lipoprotein kolesterol, mg/dL & $135.8 \pm 41.7$ & $131.4 \pm 38.4$ & 0.651 \\
\hline Total kolesterol, mg/dL & $198.3 \pm 45.1$ & $192.2 \pm 43.3$ & 0.573 \\
\hline Vücut kitle indeksi, kg/m2 & $30.5 \pm 5.1$ & $28.3 \pm 3.8$ & 0.055 \\
\hline Sistolik kan basıncı, mmHg & $139.8 \pm 10.5$ & $134.8 \pm 14.5$ & 0.112 \\
\hline Diyastolik kan basıncı, mmHg & $74.8 \pm 8.1$ & $71.9 \pm 10.7$ & 0.210 \\
\hline SYNTAX Skor & $12.6 \pm 4.8$ & $28.1 \pm 4.6$ & $<0.001$ \\
\hline Glomerülerfiltrasyon hızı, ml/min/1.73 m2 & $91.2 \pm 20.6$ & $89.3 \pm 20.3$ & 0.711 \\
\hline Eritrosit sedimentasyon hızı, mm/h & $24.1 \pm 18.1$ & $25.6 \pm 24.0$ & 0.765 \\
\hline C-reaktif protein, $\mathrm{mg} / \mathrm{L}$ & $8.9 \pm 8.5$ & $9.6 \pm 9.9$ & 0.747 \\
\hline Total lökosit sayısı, ×109/L & $7.6 \pm 2.0$ & $7.85 \pm 1.6$ & 0.572 \\
\hline Eritrosit dağılım genişliği, (\%) & $13.3 \pm 0.79$ & $13.6 \pm 0.81$ & 0.338 \\
\hline Ayak bileği-kol basınç indeksi & $0.89 \pm 0.07$ & $0.78 \pm 0.08$ & $<0.001$ \\
\hline
\end{tabular}

Tablo-4: Yüksek SYNTAX skoru varlığını öngördüren parametrelerin tek ve çok değişkenli regresyon analizi ile değerlendirilmesi

\begin{tabular}{|l|c|c|c|c|}
\hline & \multicolumn{2}{|c|}{ Tek Değişkenli Regresyon Analizi } & \multicolumn{2}{c|}{ Çok Değişkenli Regresyon Analizi } \\
\hline & Odds Oranı & $\rho$ & Odds Oranı & $\rho$ \\
\hline Erkek cinsiyet & 4.108 & 0.008 & 2.736 & 0.146 \\
\hline Hipertansiyon & 0.210 & 0.013 & 0.496 & 0.394 \\
\hline Vücut kitle indeksi & 0.888 & 0.061 & 0.903 & 0,054 \\
\hline $\begin{array}{l}\text { Ayak bileği-kol } \\
\text { basınç indeksi }\end{array}$ & -3.130 & $<0,001$ & -1.540 & $<0,001$ \\
\hline
\end{tabular}

Receiver Operating Characteric analizinde AKi'nin kestirim değeri $\leq 0.84$ alındığında, yüksek SS varlığını \%86.5 duyarlıık ve \%75.0 özgüllük ile öngördürdüğü saptanmıştır (Ĕgrinin altındaki alan: 0.84, \%95 GA: 0.73-0.92, $p<0.001)$ (Şekil 2c). Çok değişkenli analizde yaş $(\mathrm{OR}=0.87 \% 95$ $\mathrm{GA}=0.80-0.96, p=0.003)$ azalmış bir AKi değerinin $(\leq 0.84)$ bağımsız öngördürücüsü olarak tanımlanmıştır. 


\section{Tartışma}

Bu çalışma KAP'li hastalarda KAH ile EDG ve AKi arasındaki anlamlı ilişkiyi göstermiştir. Bunun yanı sıra EDG ve AKi'nin KAH varlığının bağımsız bir öngördürücüsü olduğu tespit edilmiştir. KAH şiddetinin artışıla birlikte EDG değerinde anlamlı fark saptanmazken, AKi değerinde anlamlı azalma olduğu saptanmıştır. AKi'nin artmış KAH şiddetinin bağımsız öngördürücüsü olduğu gösterilmiştir. SYNTAX skoru, KAH'nın şiddetini anjiyografik olarak belirleyen bir sınıflandırmadır. Koroner anatomiye odaklanmış olup temel amacı, lezyonların sayısı, fonksiyonel önemi, yeri ve karmaşıklğını değerlendirmektir. Yüksek SS'nun, potansiyel olarak kötü prognoz göstergesi olduğu gösterilmiştir.5 Perkütan koroner girişim geçiren akut koroner sendrom hastalarında bir yıllık ölüm, kardiyak ölüm, miyokart enfarktüsü ve hedef damar revaskülarizasyonunun bağımsız bir öngördürücüsü olduğu bildirilmiştir. ${ }^{11}$

Ayak bileği-kol basınç indeksi, alt ekstremite arteriyel sisteminin açıklı̆ını değerlendirmekte kullanılan noninvaziv bir yöntemdir. KAH'nın varlığını tahmin etmek için de yaygın olarak kullanılmaktadır. AKi ölçümüne göre PAH tanısı konulan hastalarda KV mortalite de 3-6 katlık artış söz konusudur. ${ }^{12}$ Chang ve ark. KAH şüphesi ile koroner anjiyografi yaptıkları hastalarda daha sonra AKi ölçümü yapmışlar ve AKi <0.9 olan hastalarda daha kompleks ve şiddetli koroner lezyonlarla karşılaşmışlardır. ${ }^{13}$ Bizim çalışmamızda AKi, KAH varlığı ile anlamlı bir korelasyona sahipti ve KAH varlığının bağımsız bir öngördürücüsüydü. SS ile ilişkisi incelendiğinde, SS arttıkça AKi'nin anlamlı derecede azaldığı ve artmış KAH şiddetinin bağımsız tek öngördürücc̈sü olduğu tespit edilmiştir.

Eritrosit dağılım genişliği, anisositozun derecesini yansıtan ve vücutta dolaşan eritrositlerin boyutlarındaki değişimi gösteren bir belirteçtir. Artmış EDG düzeyi demir eksikliği, vitamin B12 ve folat eksikliğinde olduğu gibi hemolizdeki artmış eritrosit yıkımını da göstermektedir. ${ }^{14}$ Artmış EDG düzeyinin KV hastalıklarda istenmeyen sonuçların öngördürücüsü olduğu gösterilmiştir. Tonelli ve ark. KAH'ı hastalarda EDG ile kalp yetersizliği, KV olaylar ve tüm nedenlere bağlı ölümler arasında ilişki olduğunu göstermiştir.6 Demirkol ve ark.'nın yaptığı çalışmada KAH olanlarda EDG düzeyi sağlıklı insanlara göre anlamlı olarak daha yüksek saptanmıştır. ${ }^{15}$ Önceki çalışmalar, EDG ile KAH şiddeti arasında bir ilişki olduğunu da göstermiştir. Akın ve ark. artmış EDG'nin akut miyokart enfarktüslü hastalarda daha yüksek SS'larıyla ilişkisini ve EDG'nin KAH şiddeti için belirgin bir öngördürücü olduğunu tespit etmişlerdir. ${ }^{16}$ Işık ve ark. KAP'li hastalarda SS kullanarak EDG ile KAH şiddeti arasında bağımsız bir ilişki bulmuşlardır.17 Bizim çalışmamızda EDG, KAH varlığı ile ilişkiliydi ve aynı zamanda KAH varlığının bağımsız bir öngördürücüsüydü. Ancak, EDG'nin KAH'nın şiddeti ile ilişkili olduğu gösterilemedi.

Eritrosit dağıım genişliğinin KAH'ın şiddeti arasındaki ilişki için olası mekanizmalardan birisi olarak aterosklerotik sürecin tümünde rol oynayan enflamasyon gösterilmiştir. CRP, ESH ve toplam lökosit sayısı gibi yükselmiş enflamatuar belirteçlerin, KAH'nın şiddeti ile ilişkili olduğu bilinmektedir.18 Geleneksel enflamatuar belirteçlerle EDG düzeyi arasında güçlü, pozitif ve bağımsız bir ilişki gösterilmiştir. ${ }^{19}$ Bu durumun sebebi olarak proenflamatuvar sitokinlerin aşırı sentezinin eritropoietin aktivitesini baskılaması olarak görülmektedir. ${ }^{20}$ Lippi ve ark. diğer faktörlerden bağımsız olarak CRP ve ESH ile EDG arasındaki ilişkiyi göstermiştir. ${ }^{21}$ Başka bir çalışmada Bak ve ark. CRP'nin AKi ile olan negatif ilişkisini göstermiştir. ${ }^{22}$ Bizim çalışmamızda da hem ESH hem de CRP EDG ile pozitif, AKi ile negatif korelasyon gösterdi. Enflamatuar belirteçlerden sadece CRP KAH varlığı ile ilişkili olmasına rağmen hem KAH varlığının hem de artmış $\mathrm{KAH}$ şiddetinin bağımsız bir öngördürücüsü
Sakarya Tıp Dergisi

2018;8(2):311-319

KARAMAN ve Ark:

KAP Hastalarında KAH'nın

EDG ve AKi ile ilişkisi 
Sakarya TIp Dergisi 2018;8(2):311-319

KARAMAN ve Ark

KAP Hastalarinda KAH'nin EDG ve AKi ile ilişkisi değildi. Bu veriler ışığında, enflamatuvar belirteçler (CRP ve ESH) ile EDG ve AKi arasında ilişki olabileceğini düşündük.

Diyabetes mellitus, hipertansiyon, sigara içimi, obezite, cinsiyet ve ileri yaş gibi aterosklerotik risk faktörlerinin KAH varlığının bağımsız belirleyicileri olduğu kadar şiddeti ile de ilişkili olduğu bulunmuştur. Nabais ve ark., akut koroner sendromu olan hastalara dayanan bir çalışmada, artmış EDG'nin ileri yaş ve hipertansiyon ile ilişkili olduğunu bulmuştur. ${ }^{23}$ Chang ve ark. KAH şüphesi ile koroner anjiyografi yaptıkları hastalarda azalmış AKi'nin hipertansiyon, diyabetes mellitus ve sigara içimi ile bağımsız ilişkisini tespit etmişlerdir. ${ }^{13}$ Bizim çalışmamızda KAH varığı açııından bakııldığında diyabetes mellitus varlığı ve ileri yaş artmış EDG düzeyleri ile hipertansiyon, hiperlipidemi varlığı ve ileri yaş azalmış AKi düzeyleri ile bağımsız olarak ilişkili bulunmuşken, KAH şiddeti açısından bakıldığında sadece ileri yaş azalmış AKi düzeyleri ile bağımsız olarak ilişkili bulunmuştur. Bu gerçekler temelinde, azalmış AKi ve aterosklerotik risk faktörleri arasındaki bağlantının, KAH'nın varlığı ve şiddeti ile yakından ilişkili olabileceğini öneriyoruz.

\section{Çalışma Kısıtlıııkları}

Çalışmamızda bazı kısıtılıklar vardı. Çalışmamız tek merkezli yürütüldüğünden, hasta sayısı görece azdı. Bunun yanında, istatistiksel analiz için EDG ve AKi'nin takip değil anlık bakılan değerleri kullanıldı. Bu nedenle EDG ve AKi'nin prognostik değerinin analizi yapılamadı. Üçüncü olarak çalışmamızda sadece hemoglobin düzeyleri ölçüldü, eksikliği sonucu EDG artışına neden olabilecek demir, vitamin B12 ve folat gibi diğer faktörler ölçülmedi.

Sonuç olarak, çalışmamızda KAH varlığında EDG'nin anlamlı derecede arttığı, AKi'nin anlamlı derecede azaldığı ve KAH varlı̆ını öngörmede EDG ve AKi kullanışlı birer değişken iken, KAH'nın şiddetini tahmin etmede AKi'nin EDG'den daha güçlü bir değişken olduğu saptanmıştır. Bu ilişkilerin daha iyi bir şekilde aydınlatılabilmesi için yeni ve kapsamlı çalışmalara ihtiyaç vardır.

Yazarlar ya da yazı ile ilgili bildirilen herhangi bir ilgi çakışması (conflict of interest) yoktur. 
1. Selvin E, Erlinger TP. Prevalence of and risk factors for peripheral arterial disease in the United States: results from the National Health and Nutrition Examination Survey, 1999-2000. Circulation. 2004;110: 738-743.

2. Aboyans $\mathrm{V}$, Criqui $\mathrm{MH}$, Abraham $\mathrm{P}$, et al. Measurement and interpretation of the ankle-brachial index: a scientifc statement from the American Heart Association. Circulation. 2012;126:2890-2909

3. Zheng ZJ, Sharrett AR, Chambless LE, Rosamond WD, Nieto FJ, Sheps DS, et al. Associations of anklebrachial index with clinical coronary heart disease, stroke and preclinical carotid and popliteal atherosclerosis: the Atherosclerosis Risk in Communities (ARIC) Study. Atherosclerosis. 1997:131:115-125.

4. Newman AB, Siscovick DS, Manolio TA, Polak J, Fried LP, Borhani NO, et al. Ankle-arm index as a marker of atherosclerosis in the Cardiovascular Health Study. Cardiovascular Heart Study (CHS) Collaborative Research Group. Circulation. 1993;88:837-845.

5. Sianos G, Morel MA, Kappetein AP, Morice MC, Colombo A, Dawkins K, et al. The SYNTAX score: an angiographic tool grading the complexity of coronary artery disease. Eurointervention. 2005;1:219-227.

6. Tonelli M, Sacks F, Arnold M, Moye L, Davis B, Pfeffer M. Relation Between Red Blood Cell Distribution Width and Cardiovascular Event Rate in People With Coronary Disease. Circulation 2008;117:163-168.

7. Ma FL, Li S, Li XL, LiuJ, Qing P, Guo YL, et al. Correlation of red cell distribution width with the severity of coronary artery disease: a large Chinese cohort study from a single center. Chin Med J (Engl) 2013;126:10531057.

8. Montalescot G, Sechtem U, Achenbach S, Achenbach S, Andreotti F, Arden C, et al. 2013 ESC guidelines on the management of stable coronary artery disease: the Task Force on the management of stable coronary artery disease of the European Society of Cardiology. Eur Heart J 2013;34:2949-3003.

9. SYNTAX Working Group. SYNTAX score calculator. http://www.syntaxscore.com. Accessed January 15, 2011

10. Norgren L, Hiatt WR, Dormandy JA, Nehler MR, Harris KA, Fowkes FG. Inter-society consensus for the management of peripheral arterial disease (TASC II). J VascSurg 2007; 45: 5-67.

11. Palmerini T, Genereux P, Caixeta A, Cristea E, Lansky A, Mehran R, et al. Prognostic Value of the SYNTAX Score in Patients With Acute Coronary Syndromes Undergoing Percutaneous Coronary Intervention Analysis From the ACUITY (Acute Catheterization and Urgent Intervention Triage StrategY) Trial. J Am CollCardiol, 2011; 57: 2389-2397.

12. Papa EDE, Helber I, Ehrlichmann MR, et al. Ankle-brachial index as a predictor of coronary disease events in elderly submitted to coronary angiography. Clinics. 2013;68:1481-1487.
13. Chang ST, Chen CL, Chu CM, Chung CM, Hsu JT, Cheng HW, et al. Ankle-arm index as a predictor of lesion morphology and risk classification for coronary artery disease undergoing angioplasty. Int J Cardiol. 2006;113:385-390.

14. Förhécz Z, Gombos T, Borgulya G, Pozsonyi Z, Prohászka Z, Jánoskuti L. Red cell distribution width in heart failure: prediction of clinical events and relationship with markers of ineffective erythropoiesis, inflammation, renal function, and nutritional state. Am Heart J 2009;158:659-666.

15. Demirkol S, Balta S, Celik T, Arslan Z, Unlu M, Cakar M, et al. Assessment of the relationship between red cell distribution width and cardiac syndrome X. KardiolPol 2013;71:480-484.

16. Akin F, Köse N, Ayça B, Katkat F, Duran M, Uysal OK, et al. Relation between red cell distribution width and severity of coronary artery disease in patients with acute myocardial infarction. Angiology2013;64:592-596.

17. Isik T, Uyarel H, Tanboga IH, Kurt M, Ekinci M, Kaya A, et al. Relation of red cell distribution width with the presence, severity, and complexity of coronary artery disease. Coron Artery Dis2012;23:51-56.

18. Drakopoulou M, Toutouzas K, Stefanadi E, Tsiamis E, Tousoulis D, Stefanadis $C$. Association of inflammatory markers with angiographic severity and extent of coronary artery disease. Atherosclerosis 2009;206:335 339

19. Krintus M, Kozinski M, Kubica J, Sypniewska G. Critical appraisal of inflammatory markers in cardiovascular risk stratifcation. Crit Rev Clin Lab Sci 2014;51:263-279.

20. Jelkmann W. Proinflammatory cytokines lowering erythropoietin production. J Interferon Cytokine Res 1998; 18:555-559.

21. Lippi G, Targher G, Montagnana M, Salvagno GL, Zoppini G, Guidi GC Relation between red blood cell distribution width and inflammatory biomarkers in a large cohort of unselected outpatients. Arch Pathol Lab Med 2009;133:628-632.

22. B k E, Marcisz C, Kadlubowska M, Michalik A, Krawczyk B, Dobrzy Matusiak D, et al. Independent Factors of Changes of Ankle-Brachial Index in Peripheral Arterial Occlusive Disease in Elderly Patients with or without Diabetes. Int J Environ Res Public Health 2016;13:1-11.

23. Nabais S, Losa N, Gaspar A, Rocha S, Costa J, Azevedo P, et al. Association between red blood cell distribution width and outcomes at six months in patients with acute coronary syndromes. Rev Port Cardio 2009;28:905-924.

\section{Sakarya Tıp Dergisi} $2018 ; 8(2): 311-319$

KARAMAN ve Ark.

KAP Hastalarında KAH'nın

EDG ve AKi ile ilişkisi 